\title{
Correction: From adolescent PCOS to adult MAFLD: opposing effects of randomised interventions
}

de Zegher F, Diaz M, Ibañez L. From adolescent PCOS to adult MAFLD: opposing effects of randomised interventions. BMJ Open Gastroenterology 2021;8: e000574. doi: 10.1136/bmjgast-2020-000574

This article has been corrected since it published online. The funding statement is now included.

This work was supported by a grant PERIS-SLT006/17/00140 from the AQU, Generalitat de Catalunya, Spain.

Open access This is an open access article distributed in accordance with the Creative Commons Attribution Non Commercial (CC BY-NC 4.0) license, which permits others to distribute, remix, adapt, build upon this work non-commercially, and license their derivative works on different terms, provided the original work is properly cited, appropriate credit is given, any changes made indicated, and the use is non-commercial. See: http:// creativecommons.org/licenses/by-nc/4.0/.

(C) Author(s) (or their employer(s)) 2021. Re-use permitted under CC BY-NC. No commercial re-use. See rights and permissions. Published by BMJ.

BMJ Open Gastro 2021;8:e00574corr1. doi:10.1136/bmjgast-2020-000574corr1

A) Check for updates 